University of Arkansas, Fayetteville

ScholarWorks@UARK

Graduate Theses and Dissertations

$12-2020$

\title{
Moisture Monitoring of a CLT Structure in a Southern Climate
}

\author{
Elizabeth Poblete \\ University of Arkansas, Fayetteville
}

Follow this and additional works at: https://scholarworks.uark.edu/etd

Part of the Civil Engineering Commons, Construction Engineering Commons, Environmental

Engineering Commons, and the Structural Engineering Commons

Citation

Poblete, E. (2020). Moisture Monitoring of a CLT Structure in a Southern Climate. Graduate Theses and Dissertations Retrieved from https://scholarworks.uark.edu/etd/3873

This Thesis is brought to you for free and open access by ScholarWorks@UARK. It has been accepted for inclusion in Graduate Theses and Dissertations by an authorized administrator of ScholarWorks@UARK. For more information, please contact scholar@uark.edu. 
Moisture Monitoring of a CLT Structure in a Southern Climate

A thesis submitted in partial fulfillment of the requirements for the degree of

Master of Science in Civil Engineering

by

Elizabeth Poblete

University of Arkansas

Bachelor of Science in Civil Engineering, 2019

December 2020

University of Arkansas

This thesis is approved for recommendation to the Graduate Council.

Cameron Murray, Ph.D.

Thesis Advisor

Tahar Messadi, Ph.D.

Samuel Zelinka, Ph.D.

Committee Member

Committee Member 


\section{Abstract}

Understanding of moisture behavior in cross laminated timber (CLT) is critical to the widespread use of CLT in construction in the United States. Currently, very little data exists on the long-term impact of moisture on CLT. The objective of this research is to collect data regarding the long-term moisture variation in the CLT panel at the University of Arkansas Adohi Hall residence hall. The climate of Northwest Arkansas is different from previously monitored buildings, as they were in the Pacific Northwest. Comparatively, Northwest Arkansas has a warmer climate with higher average annual precipitation. Waterproofing efforts are usually employed to prevent the intrusion of moisture into wood products, regardless of their application. These efforts are seen in roofing materials and insulation, among others. In the case of Adohi Hall, several layers of waterproofing membranes and insulation protect the CLT panel roof from exterior moisture intrusions. Moisture sensors were installed in 45 locations throughout the building to provide a comprehensive evaluation of the building. Locations were selected to represent different base conditions such as building envelope, communal bathrooms, interior locations, and trash rooms. Results indicate that on interior floors of the building, i.e., not the roof, CLT panels have not encountered moisture intrusions. At the roof level, moisture intrusions during construction were trapped in the CLT panels by waterproofing. This trapped moisture resulted in slow (approximately one year) drying to below acceptable levels of moisture. 
Table of Contents

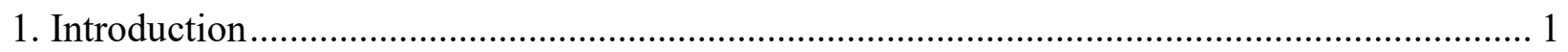

1.1 CLT introduction................................................................................................ 1

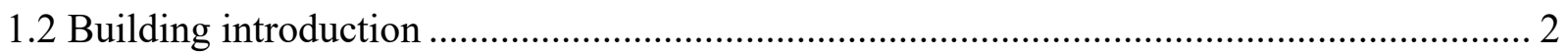

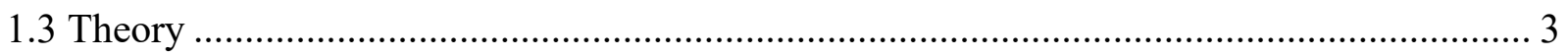

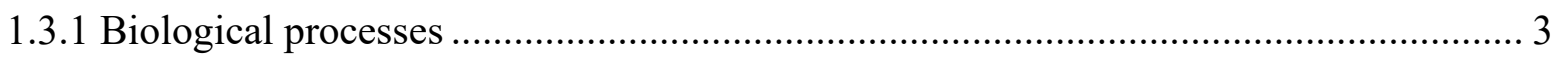

1.3.2 Impact of moisture on physical properties ...................................................... 3

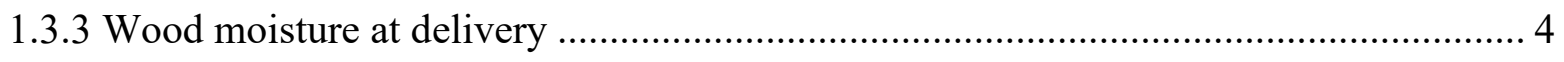

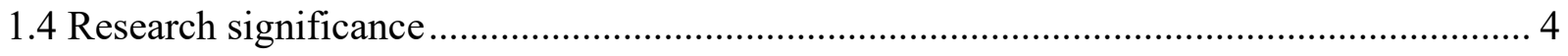

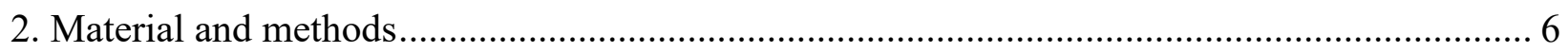

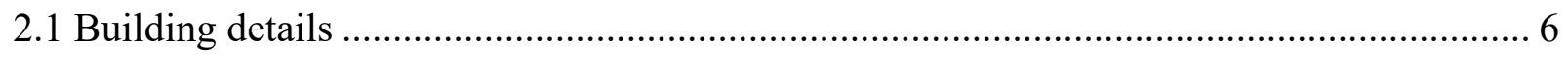

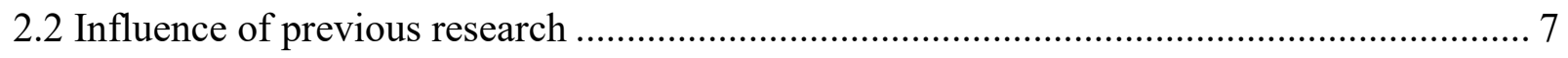

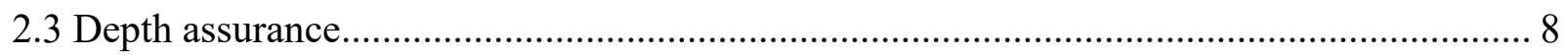

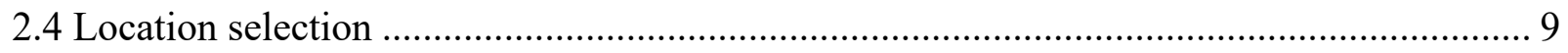

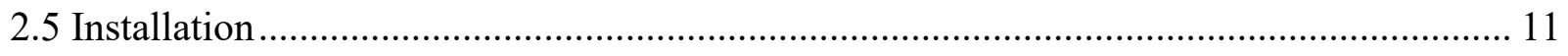

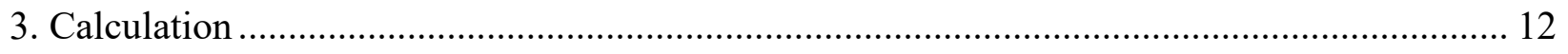

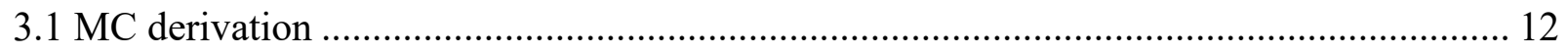

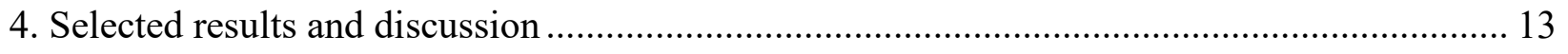

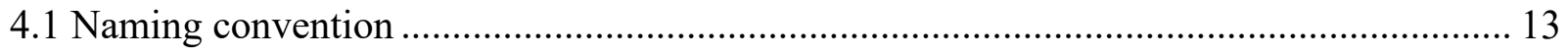

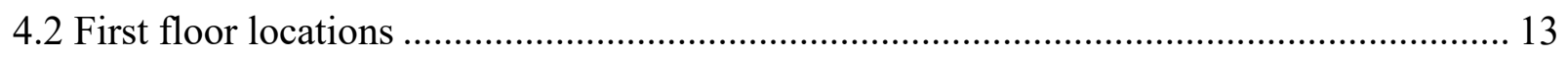




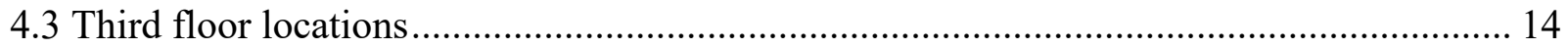

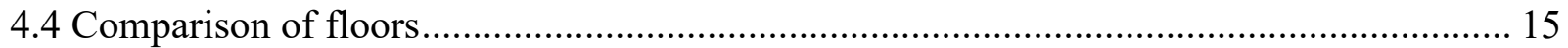

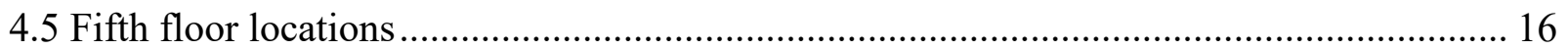

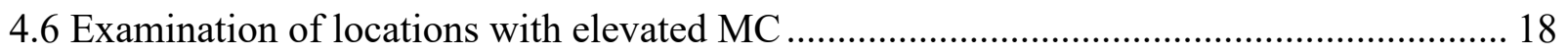

4.7 Other locations with potential for water intrusion .................................................. 19

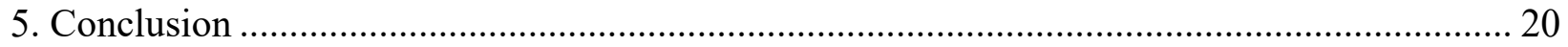




\section{Introduction}

\subsection{CLT introduction}

Cross laminated timber (CLT) is a manufactured product consisting of layers, or plies of lumber boards glued orthogonally to each other [1]. In traditional CLT production, glue is applied to wide faces to adhere plies together but is not necessarily required to adhere the edges of the boards within a ply together [2].

The thickness of a panel depends on each board as well as the number of plies. Panel length and width is limited by the manufacturer's production bed and the transportation considerations for width and length [2]. CLT panels are commonly three to seven, or more, plies thick with an odd number of plies for structural stability. A typical CLT cross section is shown in Figure 1.

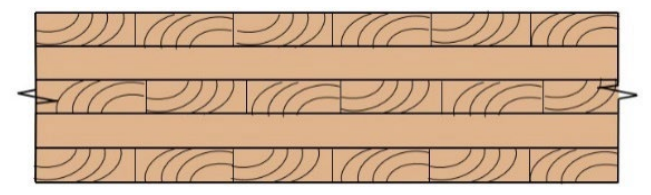

Figure 1: 5-ply CLT cross section

Unlike other engineered timber materials and traditionally used timber products, CLT does not have defined reference strength values in the National Design Standard Supplement (NDSS) [3]. The absence of reference design values is due to the variability in manufacturing, specifically in the thickness and number of plies.

CLT is relatively new and is gaining popularity as a renewable alternative to concrete or steel for mid-rise construction in particular [2]. Mid-rise projects using CLT can reach completion rapidly, since CLT elements have a high level of prefabrication and do not require large cranes or specialized equipment [2]. Also, since CLT elements are lighter than their concrete or steel counterparts, foundation size may be decreased [2]. CLT can be used for longer span floors, 
shear walls, gravity walls, and is more strong, durable, and fire resistant than light frame wood construction $[2,4]$. There are still enduring questions about its performance however, and the resistance to moisture is one of the most important considerations [5].

\subsection{Building introduction}

Adohi Hall, located on the University of Arkansas (UA) campus in Fayetteville, AR, is a student residence designed to U.S. Green Building Council's LEED Silver standards [6] and is primarily constructed of mass timber elements. Adohi Hall was the largest CLT building in the United States at the time it was constructed, in summer 2019. The hall consists of three interconnected buildings, containing 708 beds for students and faculty in the form of suite and pod student rooms, faculty apartments, as well as study lounges, kitchens, laundry rooms, community rooms, and workshop spaces. A photograph of the building is shown in Figure 2 and a building footprint for Adohi Hall is shown in Figure 3.

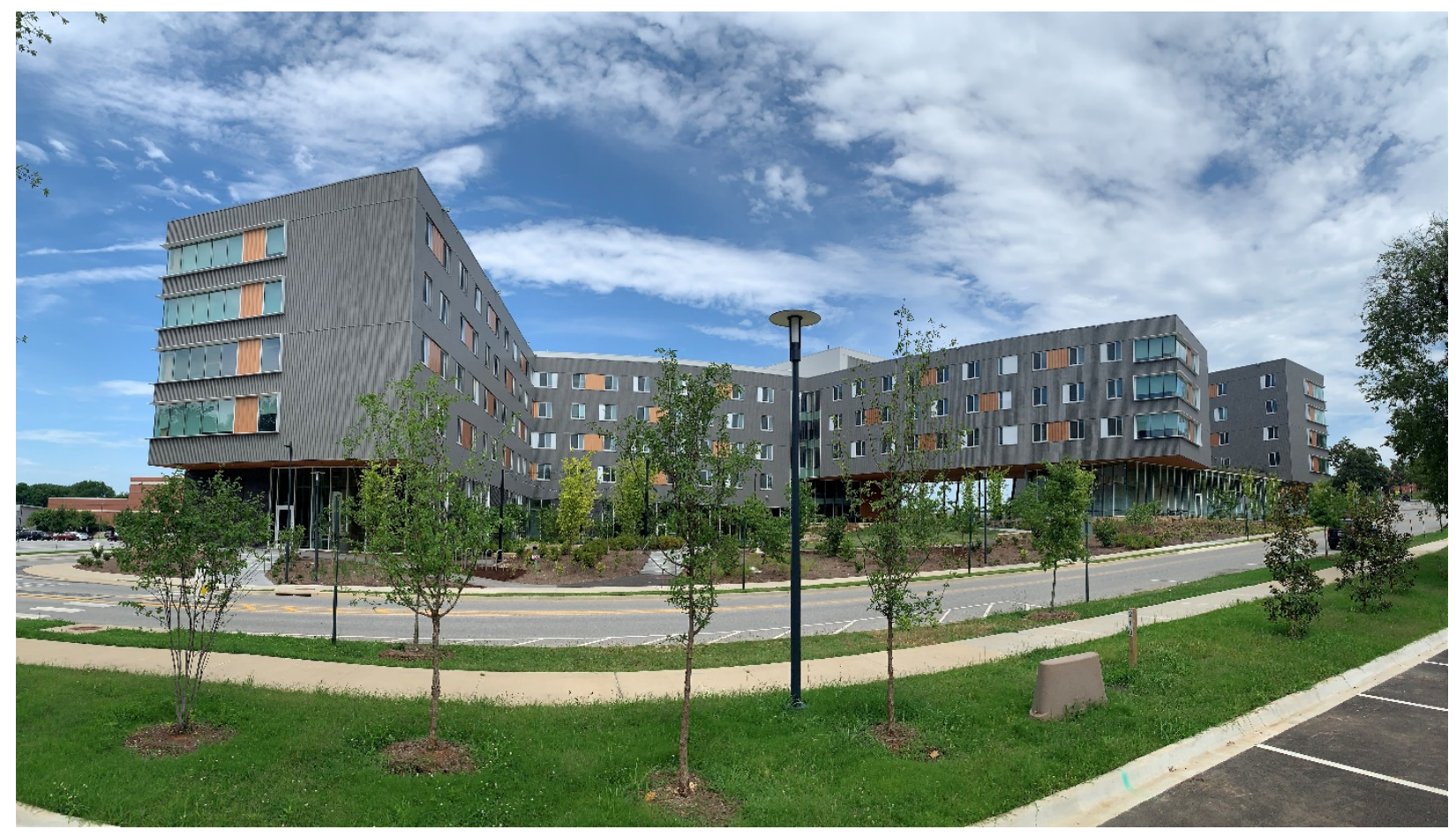

Figure 2: A photograph of Adohi Hall 

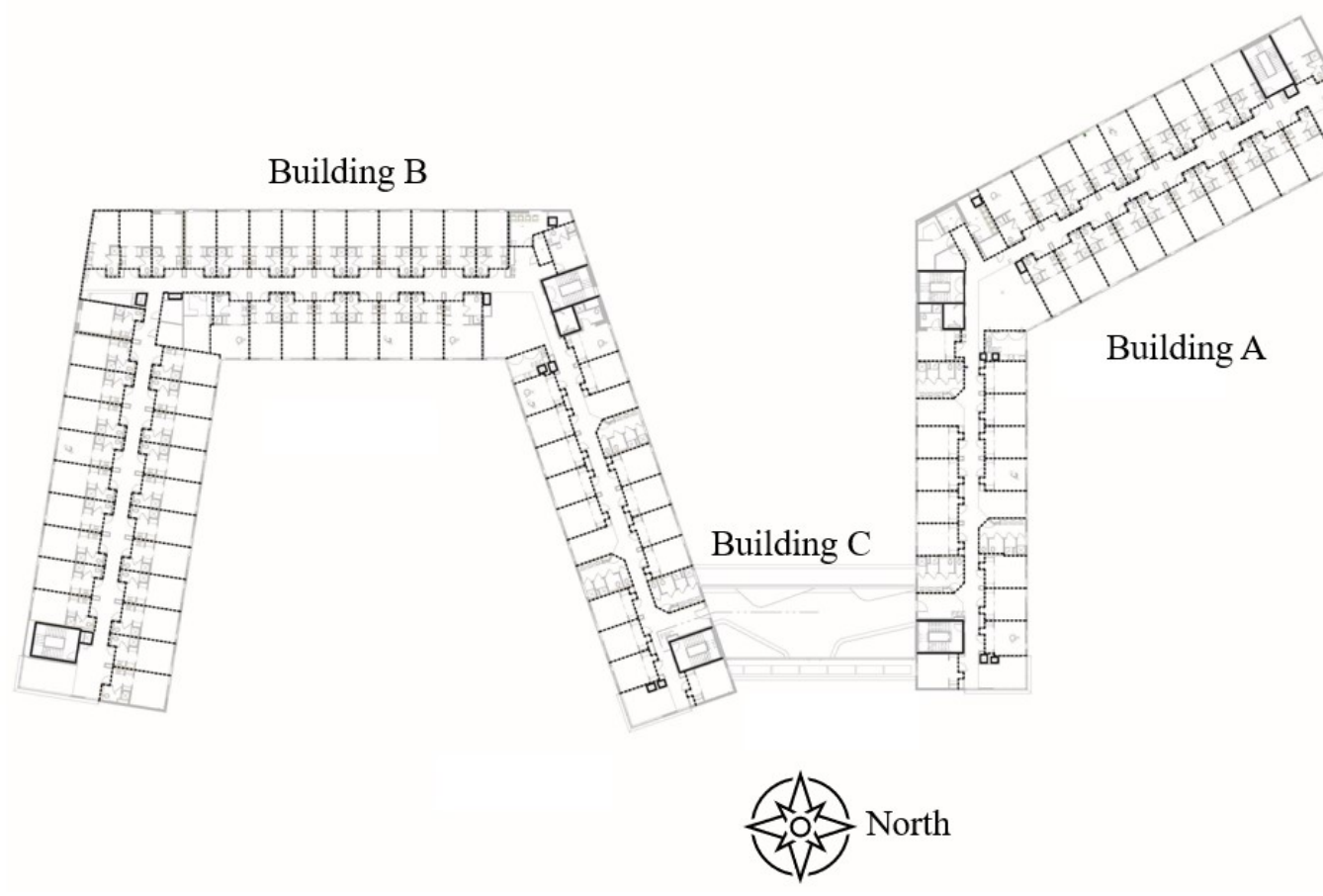

Figure 3: Building footprint [7]

\subsection{Theory}

\subsubsection{Biological processes}

Major factors that impact durability of wood structures include decay, termites, marine borers, and fire [8]. While marine borers, termites, and fire are not necessarily anticipated, decay is possible, given the climate of Northwest Arkansas. Decay occurs when fungi feed on wood products, and becomes possible when the following conditions are met: $\mathrm{MC}>20 \%$, food (in the form of cellulose or lignin), air exposure, and favorable temperatures [8]. Therefore, the main durability consideration for this structure is maintaining a MC below $20 \%$.

\subsubsection{Impact of moisture on physical properties}

CLT reference design values are applicable without a wet use factor modification when used in dry service applications, $\mathrm{MC}<16 \%$ [9]. When used outside of dry service conditions, a reference design value reduction factor is applied to bending, tension parallel to grain, shear parallel to 
grain, rolling shear, and compressive strengths as well as modulus of elasticity and minimum modulus of elasticity [9]. While there is not a defined reduction for CLT, as reference design values and adjustment factors are determined by the manufacturer, reduction in glulam (another laminated timber product) ranges from $0.53-0.875[3,9]$. Therefore, significant reductions in strength would occur in wet service conditions, $\mathrm{MC}>16 \%$.

\subsubsection{Wood moisture at delivery}

According to manufacturer standards, MC upon delivery of Spruce CLT panels is $10 \% \pm 2 \%$, regardless of panel size [10].

\subsection{Research significance}

At the $2^{\text {nd }}$ North American Mass Timber Research Needs Workshop in 2018, moisture was a common theme. In the category "durability and building physics," moisture performance of CLT in southern climates was ranked as the $5^{\text {th }}$ most pressing research need out of 29 topics and the $23^{\text {rd }}$ out of 117 topics overall [5]. Therefore, this research appears to be timely for addressing concerns of the mass timber research community about CLT structures in southern climates.

Currently, little data on the long-term impact of moisture on mass timber structures exists [11, 12]. Moisture in CLT panels is a primary durability concern because excess moisture gained during construction or by uptake from the environment can lead to mold or even degradation of physical properties [13]. Additionally, CLT is designed and manufactured to be used in dry service conditions, at a moisture content (MC) below 16\% [1].

Historically, construction of mass timber buildings in the United States has mainly occurred along the coasts, especially the Pacific Northwest [14]. Previous studies have investigated the 
changes in moisture inside CLT panels in Portland, OR [11]. According to the Köppen-Geiger climate classification [15], Portland has a warm temperate climate with dry, warm summers.

CLT is becoming a popular material in other regions whose specific climates may result in different moisture movement inside such a material. Fayetteville, AR is in a humid subtropical climate zone that tends to have more constant high humidity than the Pacific Northwest. Annual averages for high temperature, low temperature, and annual precipitation are shown in Table 1.

Table 1: Annual Weather Data for Fayetteville, AR, and Portland, OR

\begin{tabular}{|l|l|l|l|}
\hline & $\begin{array}{c}\text { Average summer } \\
\text { high temperature }\left({ }^{\circ} \mathrm{F}\right)\end{array}$ & $\begin{array}{c}\text { Average winter low } \\
\text { temperature }\left({ }^{\circ} \mathrm{F}\right)\end{array}$ & $\begin{array}{c}\text { Average annual } \\
\text { precipitation (in) }\end{array}$ \\
\hline Fayetteville, AR [16] & 90.2 & 27 & 48.51 \\
\hline Portland, OR [17] & 81.8 & 36.1 & 36.03 \\
\hline
\end{tabular}

Timber products as construction materials have been common throughout history. The durability of timber products is directly impacted by measures taken to protect it from moisture and temperature changes. Structures that are protected from the climate and the soil, with a low moisture content generally do not have durability problems. However, if these conditions are not met and preservatives are not used, durability becomes a concern [8]. Because of this, moisture mitigation strategies and a detailed understanding of the moisture uptake of wood products are essential.

In Adohi Hall, the CLT panels on the roof are protected from the elements by layers of insulation and membranes, as shown in Figure 4. Panels on each floor of the building are protected from temperature fluctuations due to the HVAC system controls. Additionally, none of the CLT 
panels are in direct contact with the ground. Durability concerns stem, therefore, from moisture content changes within the panel. These changes may arise from both external and internal moisture intrusions, or from elevated and variable $\mathrm{RH}$.

The objective of this research was to collect data on the long-term changes in moisture within the CLT panels at the UA Adohi Hall to better understand the moisture sensitivity of CLT structures in a southern climate. Long term monitoring was achieved through the installation of moisture sensors inserted into the CLT panels throughout the building.

2. Material and methods

\subsection{Building details}

Most columns and beams in the building are glulam, and the floors are built with CLT panels (except for the first story concrete podium level). Spruce CLT panels were obtained from an European manufacturer for the construction of the building. Mass timber floor/ceiling elements were left exposed for aesthetic purposes in most areas but are covered by a drop ceiling or gypsum board in hallways, bathrooms, community rooms, and kitchens. A sound mat and gypsum floor underlayment were placed before final carpeting was installed to improve acoustic footfalls and vibrations in the building. Sample cross sections for interior exposed and enclosed CLT ceiling conditions are shown in Figure 4.

Roof design, regardless of material, aims to prevent three intrusions into a building: water, vapor, and heat. The design of the roof at Adohi, as shown in Figure 4, is based on the conceptual roof design found in the CLT Handbook $[2,18]$. Recommendations in the CLT handbook are intended to prevent water or vapor intrusion since it may be harmful to the CLT [7]. 
Thermoplastic polyolefin (TPO) membrane and cover board provide moisture control and bulk water removal. Poly-iso insulation provides thermal control to the interior of the building. The vapor retarder sheet and underlayment provide vapor control and secondary moisture control.
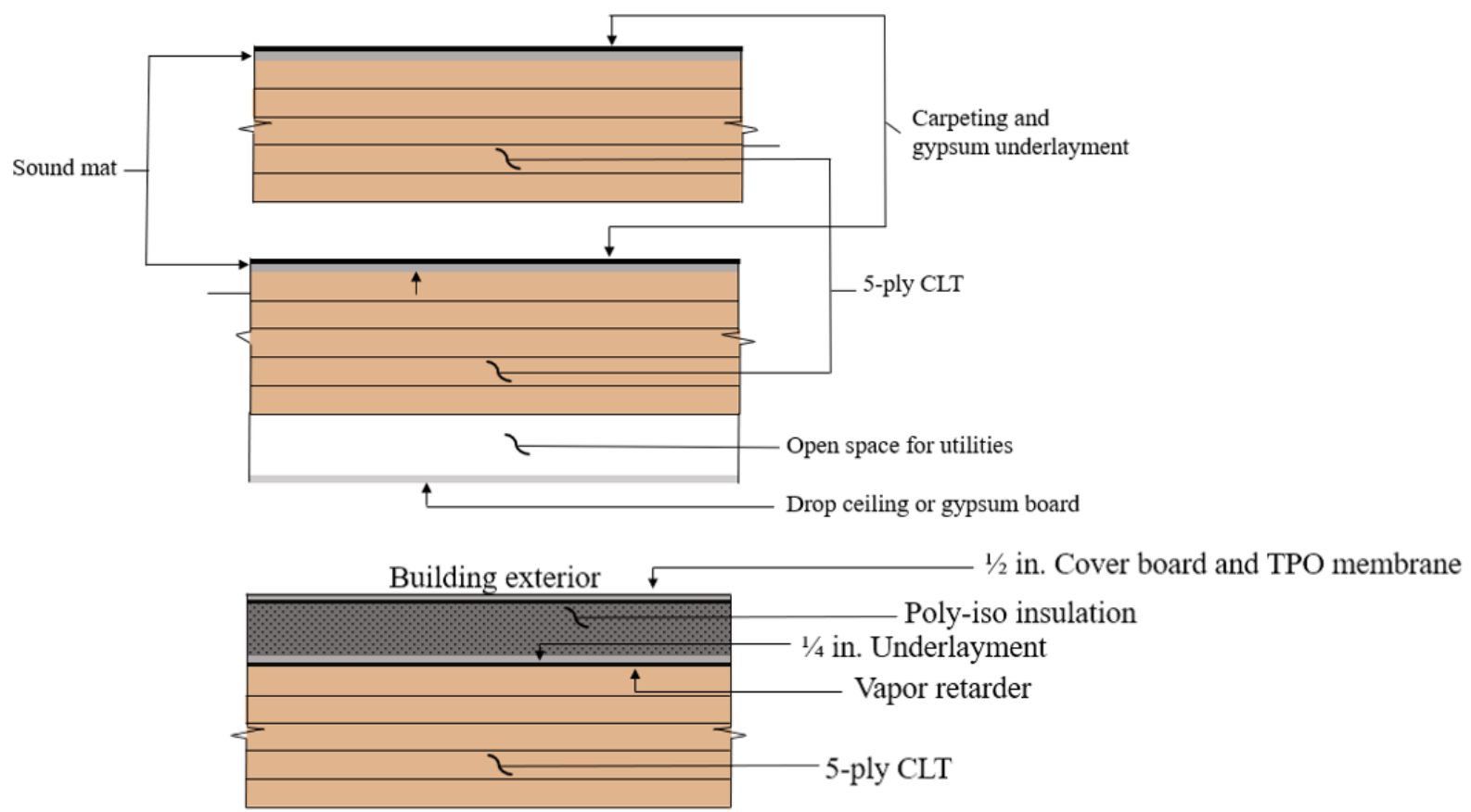

Building interior

Figure 4: Ceiling and roof sections

\subsection{Influence of previous research}

Pin type sensors, such as those outlined in Kordziel, et. al, were selected since specific depths could be targeted for monitoring [11]. Pin type sensors used a battery to create a current, which traveled down one pin, across the sample medium, and into the other pin. The resistance encountered in the sample was used to calculate wood moisture equivalent (WME) in the CLT sample [19]. Calibration of a conversion for WME to moisture content (MC) was determined by oven drying testing according to ASTM D4442-16: Standard Test Methods for Direct Moisture Content Measurement of Wood and Wood Based Materials [20]. 


\subsection{Depth assurance}

As designed, Omnisense S-160 pin type moisture sensors penetrate only 2 in. into a sample material, where the current was isolated to the portion of screw extending past the plastic legs. Since this research targeted depths more than 2 in., the protective legs were entirely removed.

Without the legs, the current passed through the area of highest moisture, i.e. the area of least resistance, regardless of screw length. Heat shrink tubing was purchased to isolate the path of current to only the targeted depth. The use of heat shrink tubing allowed for uniform thickness and therefore for consistent current resistance continuously down the length of the covered screw shank. The last $1 / 2$ in. of each screw was left exposed, as shown in Figure 5. Stainless steel screws of various lengths were selected to target different depths in CLT. Since measurements were taken at depths reaching the center of $1^{\text {st }}, 3^{\text {rd }}$, and $5^{\text {th }}$ ply, appropriate screw lengths were selected, also shown in Figure 5. Sensors were placed in groups of three, or clusters, to target different plies in the same panel area, as shown in Figure 5. These ply locations were selected to establish the moisture gradient in the panels and determine if there was any greater moisture at surfaces close to the envelope or to conditioned spaces compared to the panel interior.
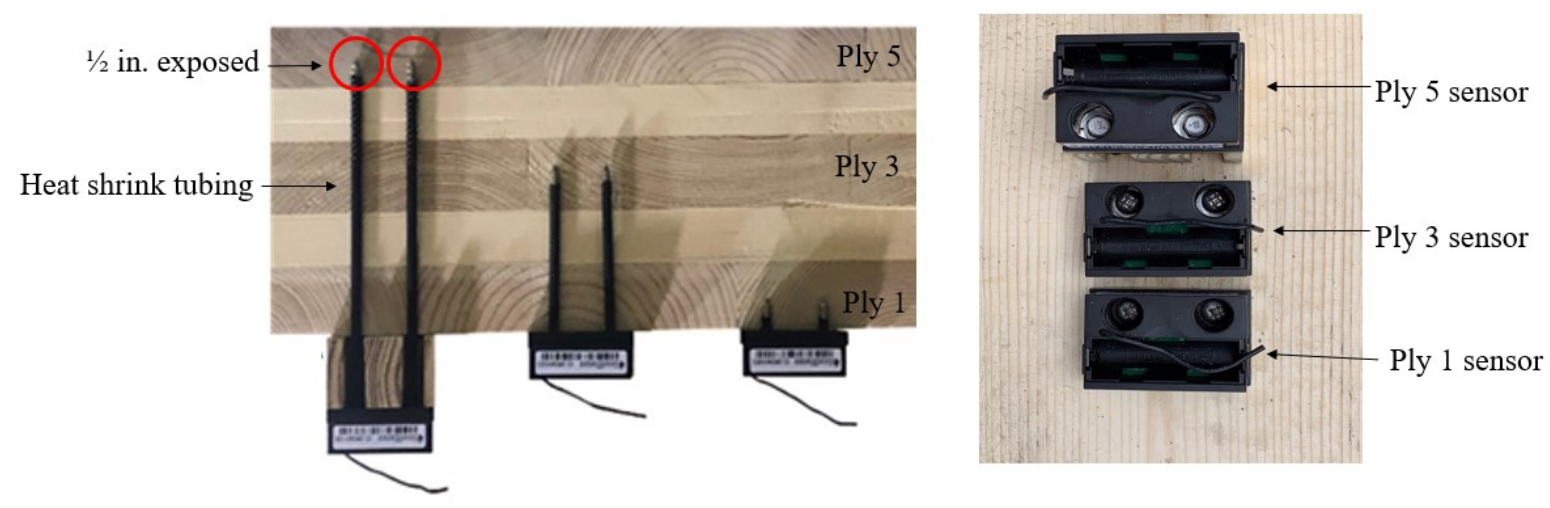

Figure 5: Pin depth and typical cluster layout 
Unlike previous research in moisture monitoring of CLT panels, notches in the CLT were not required to conceal the sensors [11]. Instead, pilot holes were drilled $1 / 2$ in. short of final depth on the underside of the panel. The use of pilot holes protected the heat shrink tubing from damage during installation and ensured the only portion of the screws in firm contact with CLT was the exposed portion. This method was considered advantageous since it maintained the original cross section of the panels.

\subsection{Location selection}

Locations were selected to capture a variety of moisture and temperature conditions throughout the building, especially areas near the envelope or where water was expected. Many student rooms were instrumented. All student rooms were located next to the building envelope, and sensor clusters were placed at the ceiling and directly next to the windows. Areas near building plumbing and drains were also instrumented, specifically: communal kitchens and bathrooms, as well as laundry rooms. Two additional areas were selected which were not expected to have extremes of moisture, one with climate control and a dropped ceiling, the other without climate control and an exposed CLT ceiling. These were both located in interior locations far from the building envelope. Hallway sensors provided the most insulated readings, as they were in an enclosed dropped ceiling farthest away from the building envelope. Several areas of the building HVAC conditioned, such as trash rooms, utility rooms, and storage closets. These were internally located environments and enclosed by the building envelope and were monitored for comparison to the HVAC controlled spaces. All five floors in Adohi Hall contained a combination of these conditions, and a typical layout of sensors (on the second floor of building A) is shown in Figure 6. Successful sensor cluster installation was dependent on available empty areas in the plenum space and varying layouts respective to each floor, therefore the exact sensor 
location varied slightly from floor to floor. Some additional sensor locations were selected during the installation and were not repeated on every floor, such as locations near bathrooms, a janitorial closet, an HVAC air handler room, and under a green roof. While most of the sensors were in upper floors of Building A, as shown in Figure 6, some of these areas identified while on site were on the first floor of Building A or in other buildings. The most notable of identified areas were on the first floor of Building A and in Building C, as shown in Figures 7 and 8.

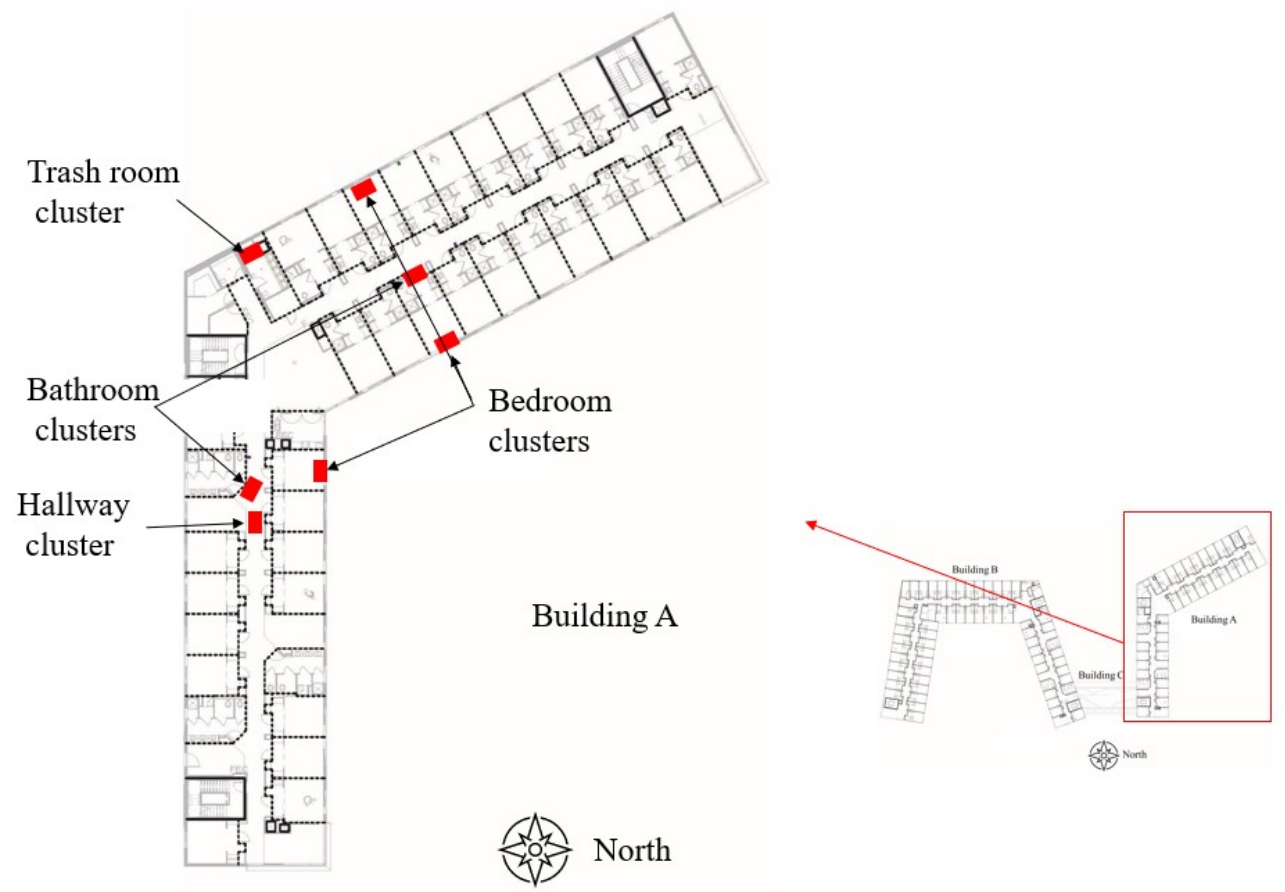

Figure 6: Building A typical sensor locations [7] 


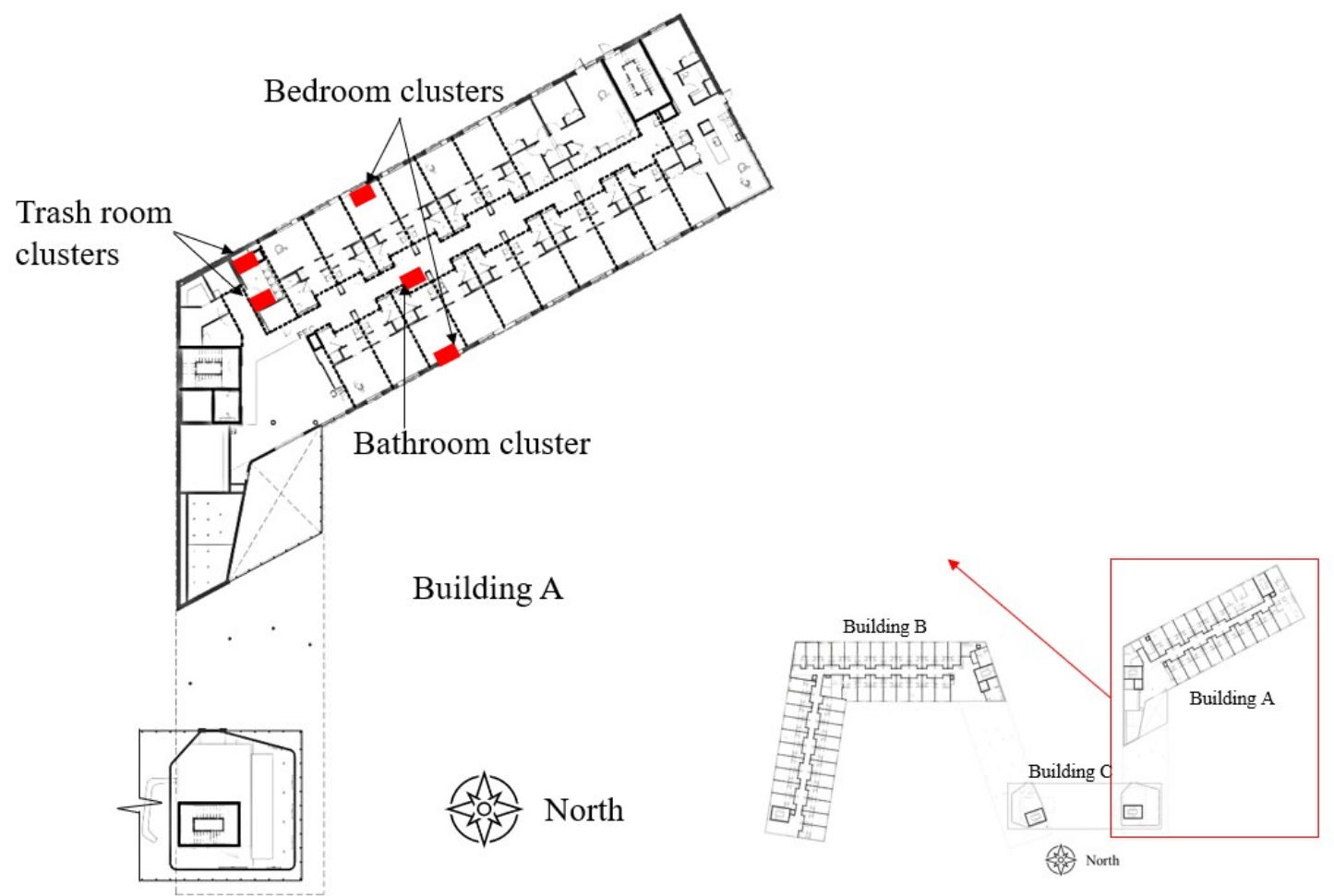

Figure 7: Building A floor 1 locations [7]

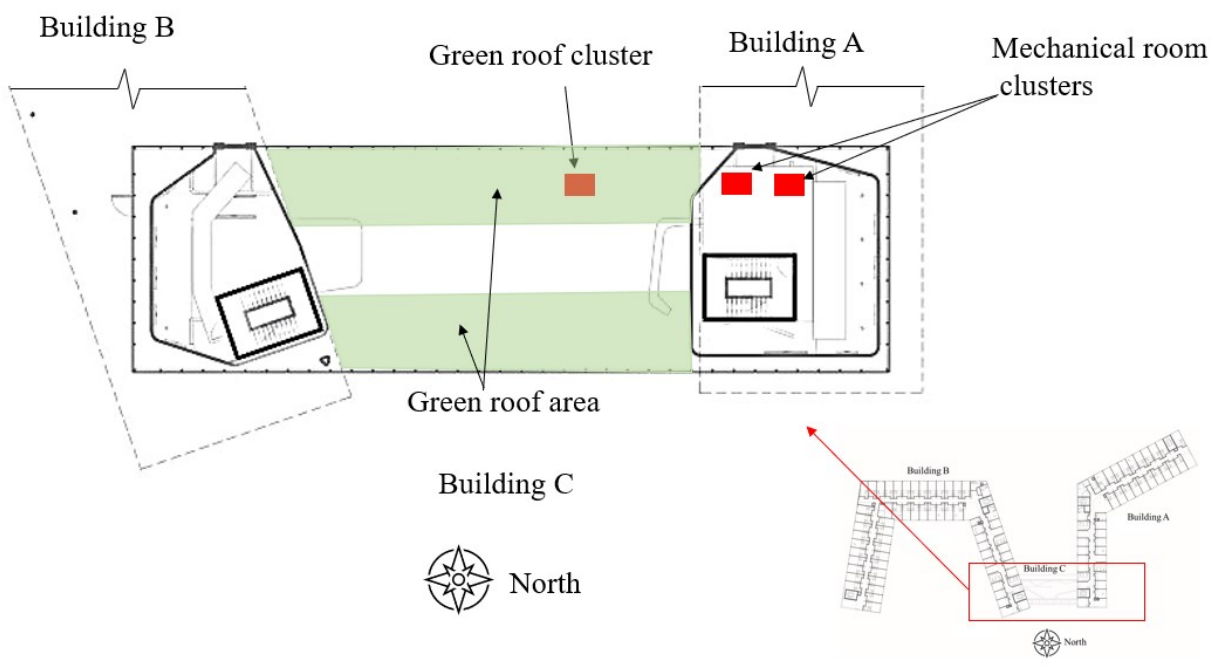

Figure 8: Building $\mathrm{C}$ sensor locations [7]

\subsection{Installation}

The installation procedure for the sensors included the following steps: the pilot hole locations were marked on CLT using a template and drilled, sensors were installed in a cluster of three (to 
monitor the first, third, and fifth ply). A total of 45 locations and 134 sensors were instrumented. In one location, under the green roof, only two sensors were possible due installation limitations from a different ceiling detail. All sensors were installed after the panels were erected, while the building was already enclosed but prior to the operation of the HVAC system.

\section{Calculation}

\subsection{MC derivation}

Sensors used in this research were designed to detect moisture in a variety of construction materials, rather than just wood. For this reason, data collected directly from the sensors are reported in terms of WME, an approximation of what the moisture content would be if the sensor were installed in an unspecified wood sample [19]. Sensor calibration was performed using ASTM D44412-16, and results are summarized in Figure 10. The actual MC was determined by mass while drying CLT samples in an oven. Comparisons indicate an nearly linear relationship between MC and WME and a 2.17\% difference between MC and WME. This comparison is not applicable at $\mathrm{MC}<5 \%$, as the lower threshold for sensor readability is $7 \%$ WME. Based on the calibration of the sensors, a conversion of WME to MC followed the equation below, from the calibration results in Figure 9:

$$
M C=W M E-2.17 \%
$$

Readings below $\mathrm{MC}=5 \%$ were reported as $5 \%$ in this paper since the actual $\mathrm{MC}$ could not be determined. 


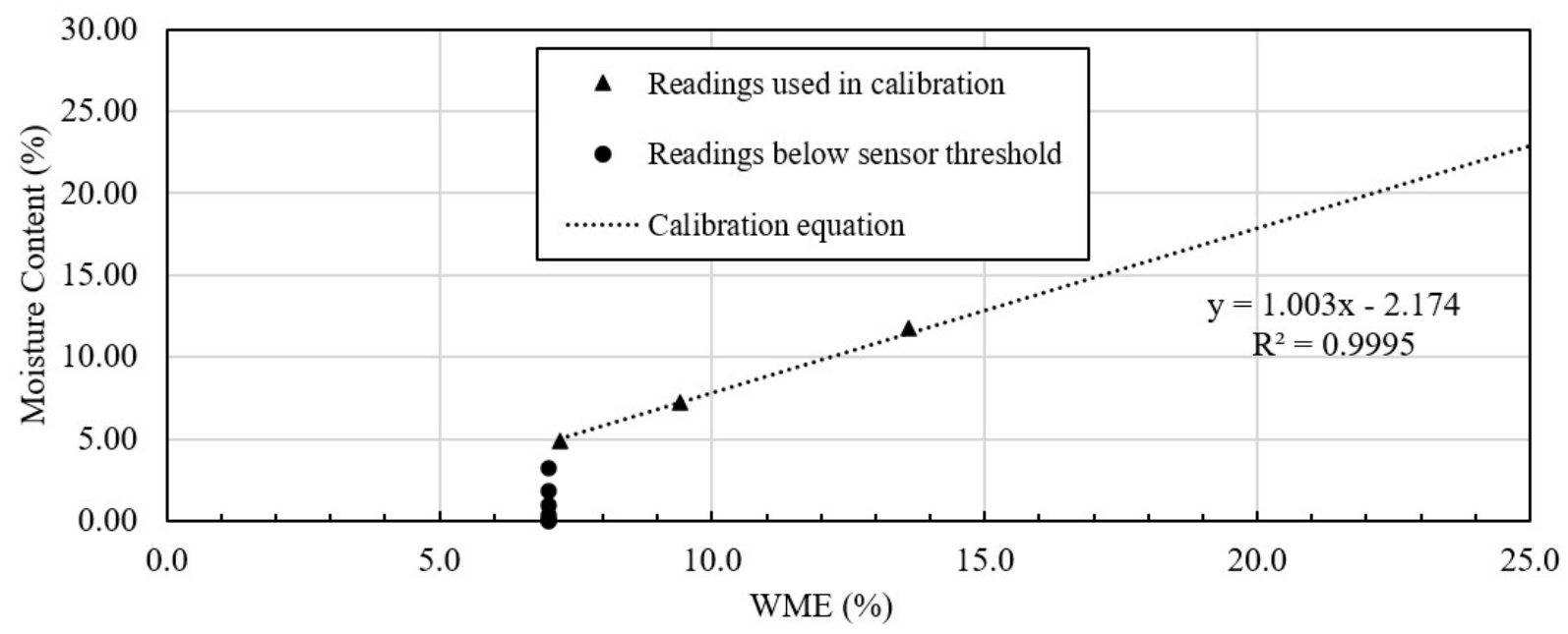

Figure 9: Calibration Results

4. Selected results and discussion

\subsection{Naming convention}

Each sensor cluster contained three sensors to read three plies: first, third, and fifth (from bottom to top of panel). For each cluster location, sensors were identified as $-1,-3$, and -5 to denote the ply which the sensor was reading. For example, the sensor reading the northern mechanical room fifth ply was denoted "Mechanical N-5".

\subsection{First floor locations}

First floor locations were of interest because of the differing floorplan, as shown in Figure 7. In lieu of a wing for additional bedroom and bathrooms, the southeast wing includes large doors for entry and exit from the building. Despite infiltration of humidity and heat from exterior doors, first floor locations remained dry, as shown in Figure 10. Sensors of highest and lowest values are shown in this paper to highlight the extremes of moisture activity on the floor. The bedroom location, near the building envelope, provided the highest moisture content on the floor, but remained in dry service conditions throughout monitoring. Values below $5 \%$ are artificially shown as $5 \%$, the lowest value that could be accurately measured. The bathroom location, near 
the hallway which leads to the exterior doors, displayed a relatively constant results, implying that the frequent opening and closing of exterior doors had little effect on the CLT panel. A trend of decreasing MC is apparent. It is possible (based on results from other floors) that the MC in these panels was higher when the panels were erected and were exposed to the elements. Clearly, now that the panels have been enclosed for a year the MC has stabilized to acceptable levels.

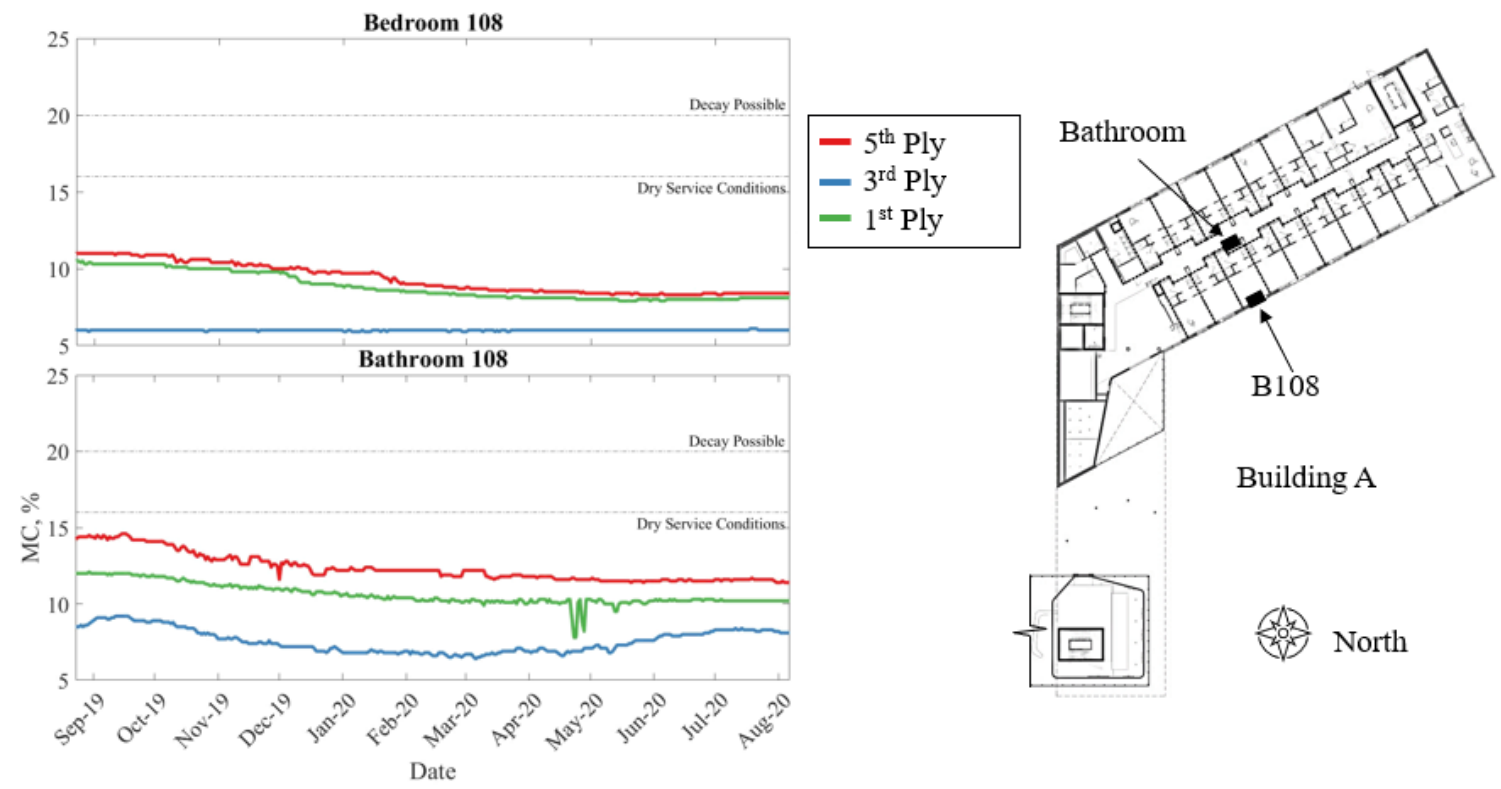

Figure 10: First floor results [7]

\subsection{Third floor locations}

Third floor locations represent perhaps the most insulated areas of the building since they were two floors away from the ground level's exterior doors as well as the fifth floor's roof system. In addition to protection from the building exterior, the third floor also had the most spacious plenum area. With fewer water, sewer, etc. pipes and smaller HVAC routing, the third floor CLT panels were also exposed to less moisture in the form of condensation and steam. Sensors with the highest, near average and lowest readings are shown in Figure 11 to represent the typical conditions on the third floor. Only one sensor approached the threshold for dry service 
conditions, but that area quickly dried to well below dry service conditions. As mentioned in the discussion of the first floor, it is likely that these locations were more moist during construction but have since dried to acceptable levels. For both bedroom and bathroom locations, the fifth ply had the highest MC compared to third and first plies.

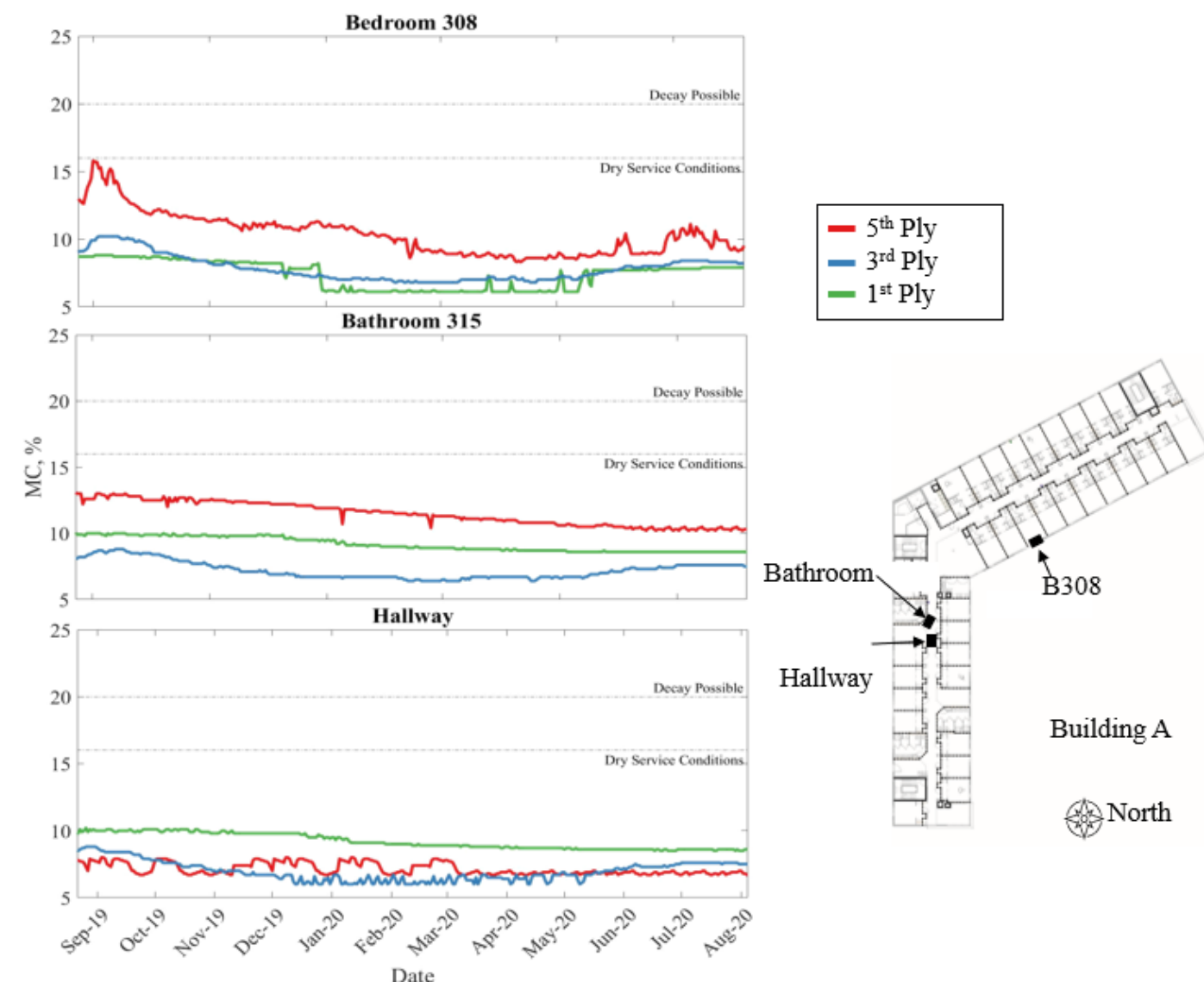

Figure 11: Third floor results [7]

\subsection{Comparison of floors}

Bedroom \#08 (where \# denotes the floor number) was an area that was monitored on each floor. Figure 12 shows results from the first, third, and fifth floors. To improve figure readability, these sensors were selected to represent the building and provide a general view of typical conditions. 
Figure 12 shows the results from the fifth ply, which almost always has the greatest MC. All sensors remained within dry service conditions, despite their proximity to the building envelope.

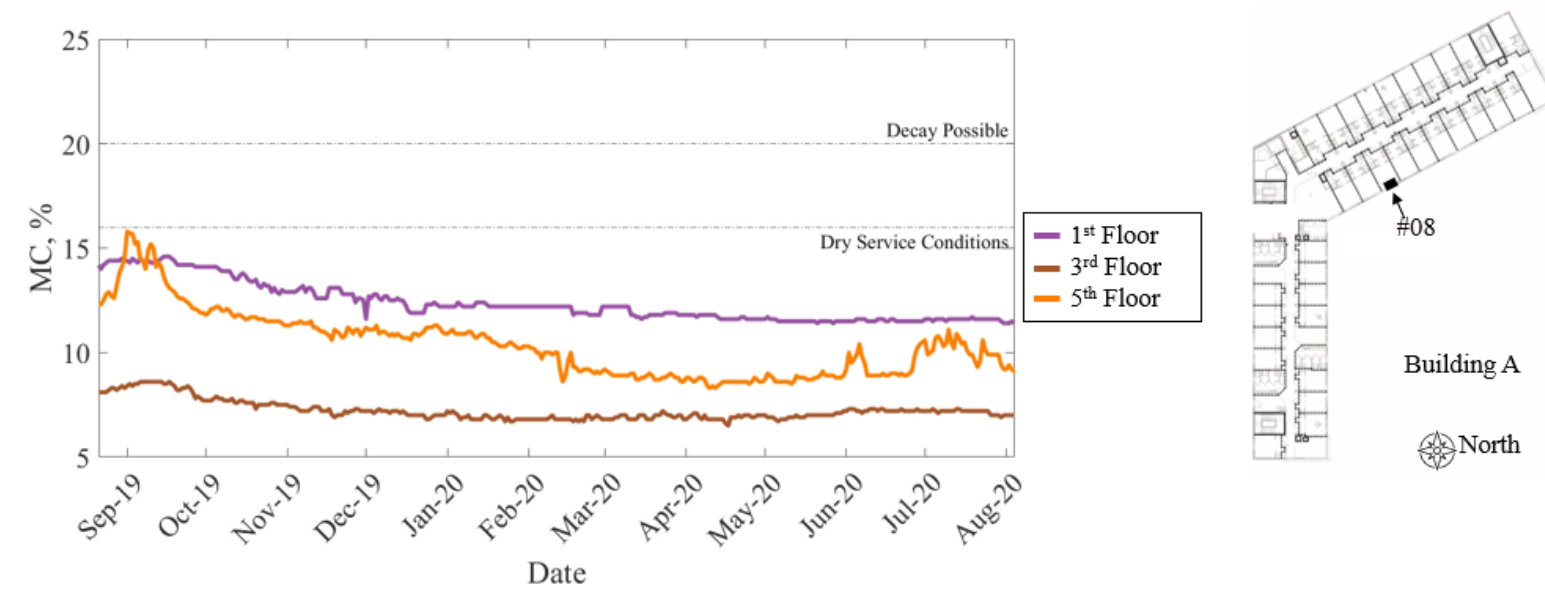

Figure 12: Selected bedroom results [7]

\subsection{Fifth floor locations}

The CLT panel which functions as the ceiling of the fifth floor also acts as the roof for the entire building. For this reason, locations on this floor were of the greatest concern since rain and snow result in roof moisture proper drainage and waterproofing was required to protect the panels.

Building A, where most sensors are located, was constructed last. The protective sheets covering the CLT panels for delivery were removed to install the panels. The exposure of these panels to water and moisture during the period between removal of this protective sheet and when the building is fully enclosed can lead to high MC. It is recommended to cover the CLT during construction, but this is difficult in practice. In addition to pre-construction moisture in some panels, roof panels were exposed to rain and moisture prior to waterproofing. Figure 13 shows the drying trend of the fifth ply (nearest to building exterior) of the fifth floor. During installation, locations were observed where moisture intrusion had caused staining, especially 
close to the edges of the building and around connection locations, as show in Figure 13.

Obviously, moisture affected the panels during construction, therefore the internal moisture measurements were important to determine if this moisture dissipated once the building was occupied. The fifth-floor sensors provided useful information about the change in moisture from construction to occupancy since these panels were the last to be installed.

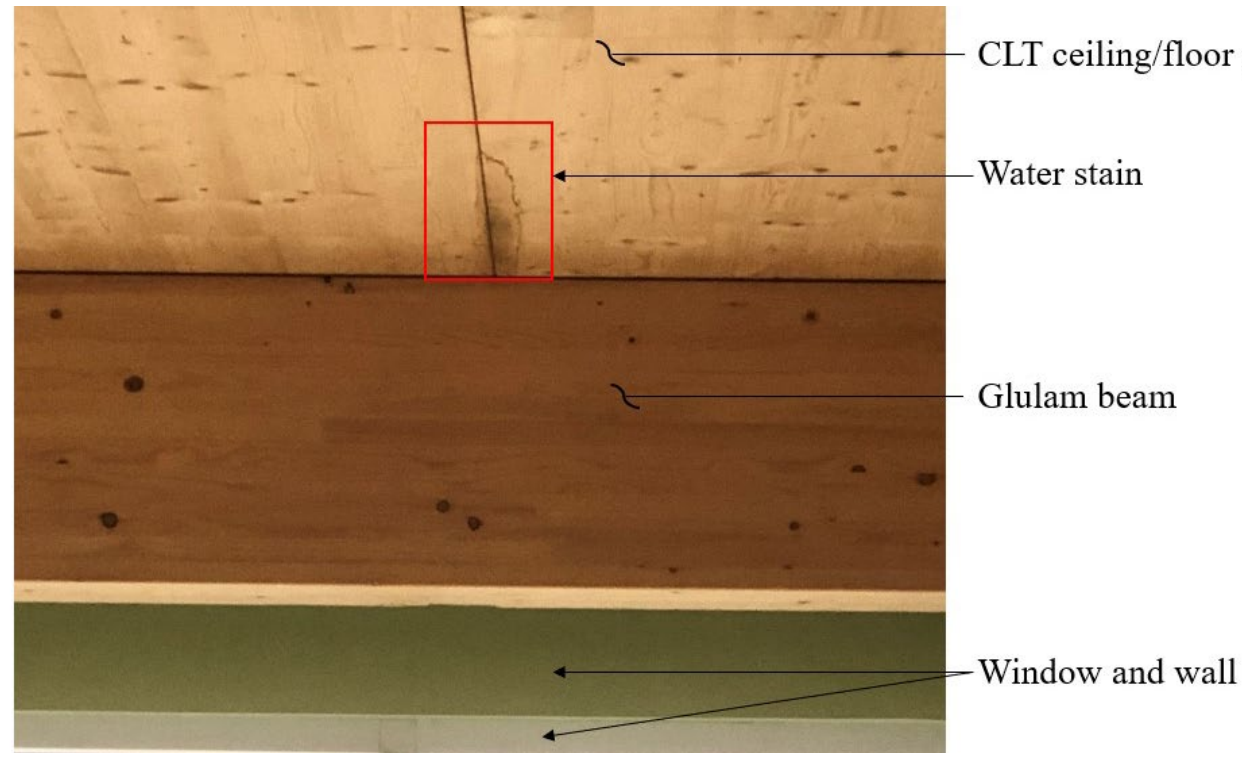

Figure 13: Water stain on CLT panel

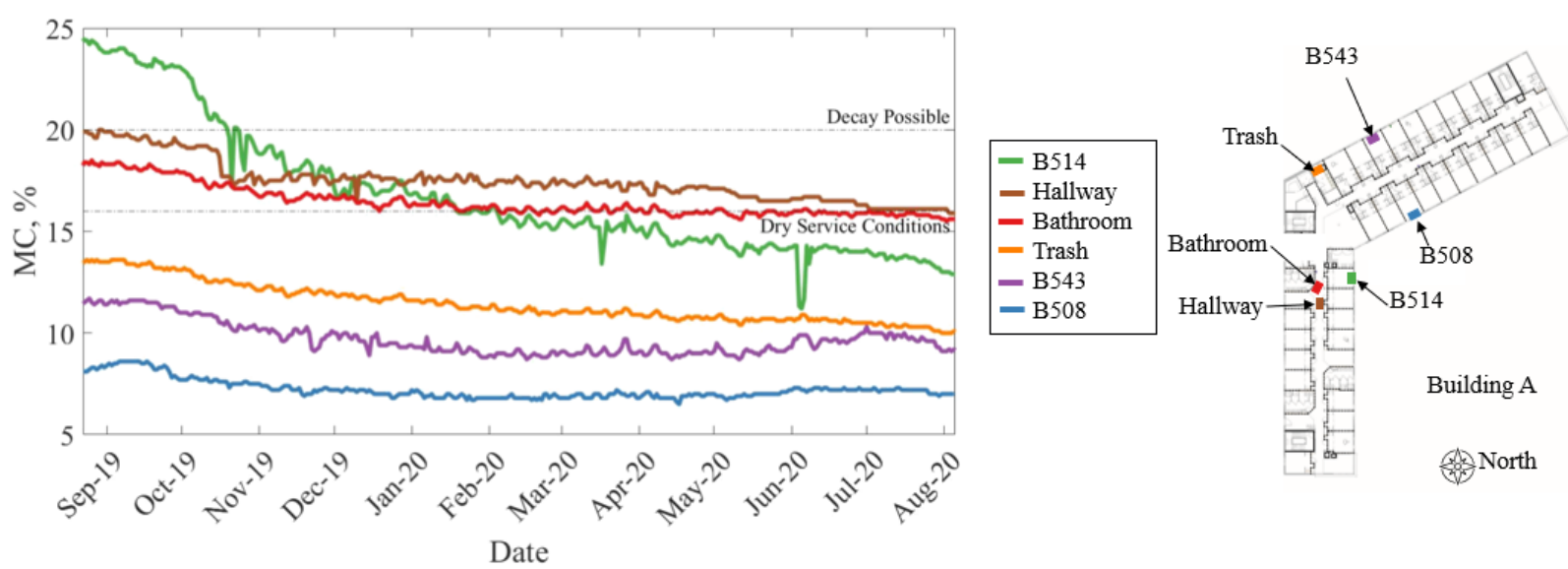

Figure 14: Fifth floor, fifth ply results [7] 
Figure 14 shows only the $5^{\text {th }}$ ply (closest to the exterior) measurements from selected locations on the $5^{\text {th }}$ floor. Three locations were outside of dry service conditions, and one was above the threshold for possible decay at the time the $5^{\text {th }}$ floor sensors were installed. These locations were in an area with standard waterproofing and roofing insulation between the CLT panel and the outside of the building. The other three locations shown in Figure 14 had a concrete topper supporting a large HVAC air handling unit, as shown in Figure 15. Locations under the concrete topper remained within dry service conditions and provided similar results to those on the first or third floor. All sensors have shown a trend of decreasing MC over time. Since the sensors were installed, however, those in the hallway and bathroom appear to be drying at a slower rate at the time these data were collected (one year of sensor readings).

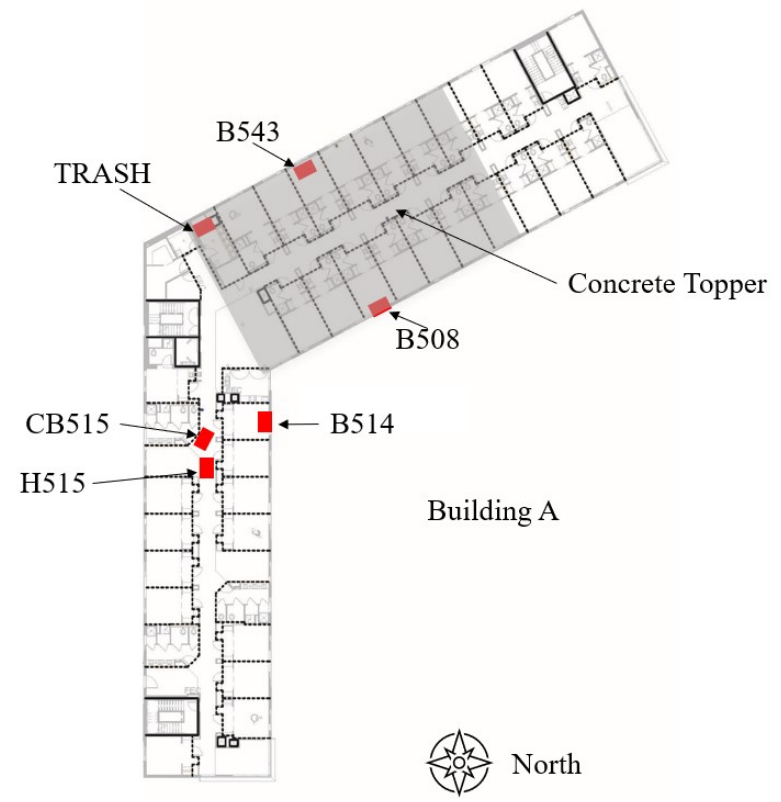

Figure 15: Concrete topper location [7]

4.6 Examination of locations with elevated MC

Although the fifth-floor locations included plies which were above dry service conditions, it is important to emphasize that the entire cross section was not above dry service conditions. As 
shown in Figure 16, the first and third plies remained within dry service conditions during the first year of monitoring. In fact, the first ply for all three locations was nearing the lower threshold of sensor readability, $\mathrm{MC}=5 \%$.

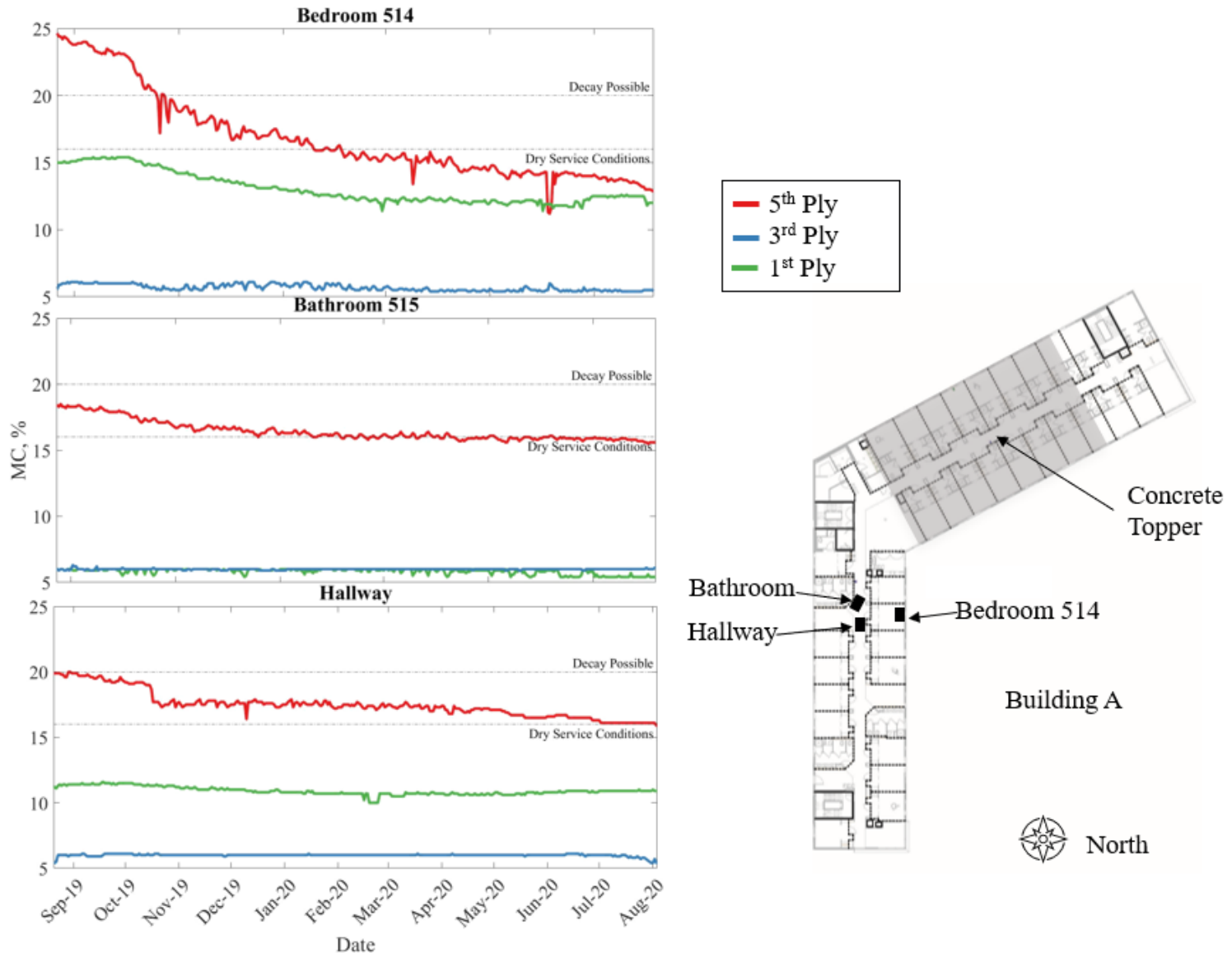

Figure 16: Full depth examination of elevated MC clusters [7]

4.7 Other locations with potential for water intrusion

While on site for initial sensor location planning, an area of interest for potential water intrusion was building $\mathrm{C}$, which has both a green roof and large mechanical rooms containing water controls for the green roof as well as HVAC air handlers. Despite the increase in both moisture and water moving through these areas, panels in these areas remained within dry service conditions, as shown in Figure 17. Unfortunately. the fifth ply of the green roof sensors could not 
be instrumented due to accessibility issues resulting from the ceiling detail in that location. The trend from the third ply suggests that there are no moisture issues below the green roof at the time of this writing.

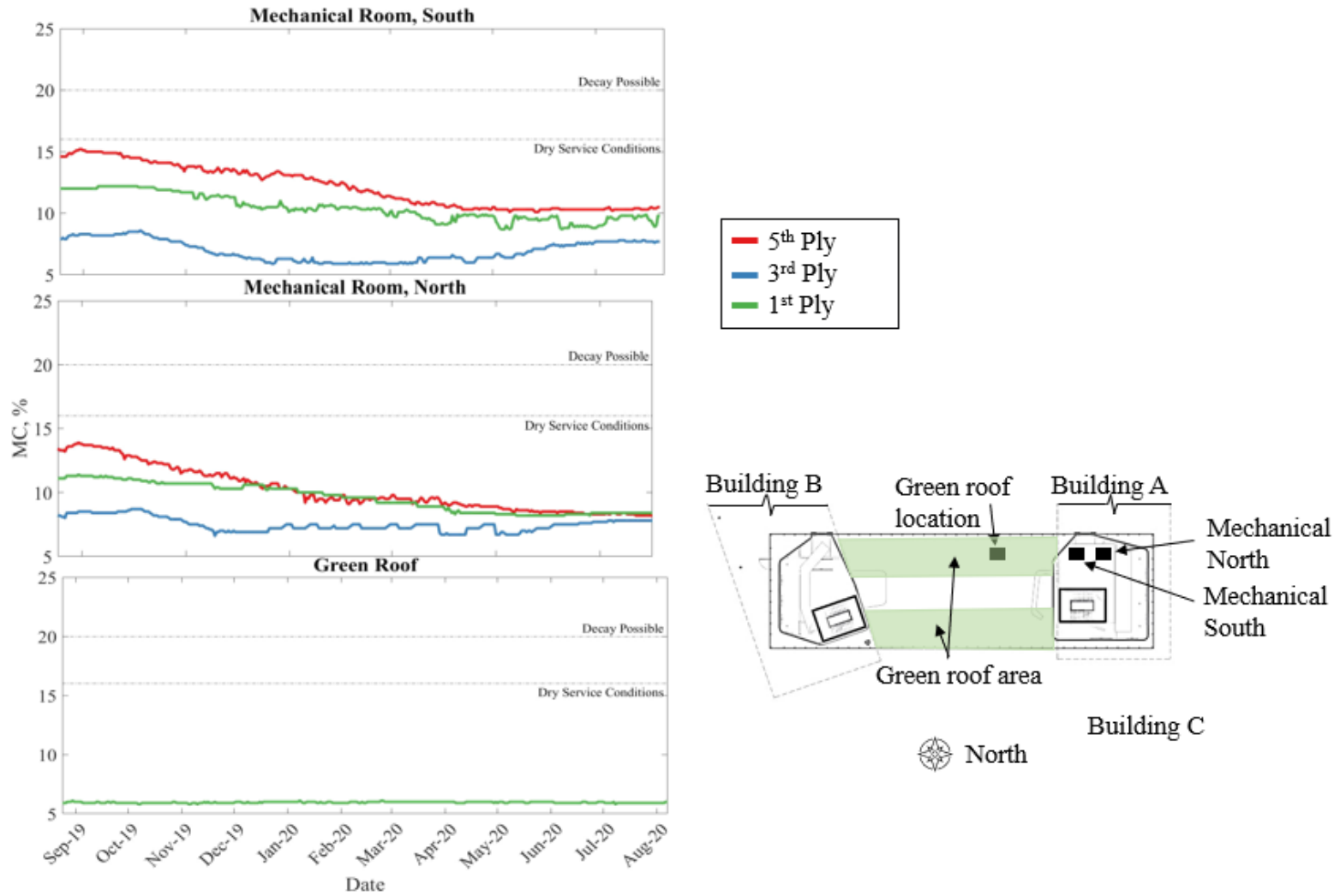

Figure 17: Building C sensors

\section{Conclusion}

The primary goal of this study was to collect long-term moisture monitoring data of CLT panels in a southern climate to determine the impact of moisture on durability. Data collection was achieved through long term monitoring of 134 sensors in 45 locations throughout different wings of Adohi Hall, a residence hall on the UA campus.

While there is currently no evidence of moisture increase within the building, moisture uptake from the construction process appears to have contributed to elevated moisture content in certain 
areas of the building. In most scenarios, moisture has slowly decreased to below the NDS prescribed dry service conditions of $16 \%$ [9]. All locations below the fifth floor, which have only a sound mat and flooring on the top side of the panel, as shown in Figure 4, were below dry service conditions. Since the sound mat and flooring materials are permeable to vapor, this likely resulted in a faster drying rate for interior panels.

Results from first floor sensors indicated that temperature and humidity change from the proximity to exterior doors had little impact on $\mathrm{MC}$ in the panels. While all first-floor sensors remained under dry service conditions, both locations also showed that fifth ply sensors had the highest MC, followed by third ply, then first ply. This MC gradient was probably created through wetting of the panels before construction, as the fifth ply would be exposed to most moisture from precipitation.

Third floor locations provided similar results to first floor locations. In all locations, all sensors remained under dry service conditions throughout monitoring. In bedroom and bathroom locations, the same MC gradient as first floor locations was observed. The hallway location provided different results, as the fifth ply had the highest MC with first and third plies providing similar results.

When comparing the same bedroom location on different floors, the first and fifth floors had the highest fifth ply MC. The third floor, fifth ply sensor typically remained at a constant MC. Again, in all cases, $\mathrm{MC}$ remained below dry service conditions throughout monitoring.

Roof panels, unlike all others in the building, have layers of waterproofing applied to the top surface to protect them from post-construction moisture intrusions in the form of rain, hail, snow, and elevated humidity. Installation of vapor barriers as part of the waterproofing system have 
proved effective in blocking exterior moisture from entering the roof panels. However, the vapor barrier has also potentially inhibited the escape of initial moisture in roof panels. This drying inhibition has led to prolonged time with MC above dry service conditions and above the threshold for decay. It is also important to note that in areas with a different waterproofing system, i.e. where there is a concrete topper for an air handler, drying was not inhibited. These results are consistent with similar previous research, in which roof panels with a vapor impermeable membrane remained above $20 \%$ MC for nearly a year [11].

Similar to locations away from the roof in building A, all those in building $\mathrm{C}$ remained under dry service conditions. While the fifth ply under the green roof could not be monitored, first and third plies provided results near the lower threshold for sensor readability. The same MC gradient as in building A third floor locations was present in building $\mathrm{C}$ mechanical rooms.

Further data collection is required for other mass timber products and distinct construction sequences in differing climates. Protecting roof panels from moisture intake before construction and application of waterproofing is recommended to reduce the probability of decay or reduced physical properties, since drying occurs so slowly with the presence of waterproofing systems. Any steps that can be practicably taken to reduce moisture increases during construction will prevent unwanted wetting, especially at the roof level. After one year of monitoring, however, the CLT panels in Adohi Hall, moisture does not appear to be an enduring issue for the durability of the building. 
Works Cited

[1] APA - The Engineered Wood Association, "Standard for Performance-Rated CrossLaminated Timber," American NAtional Standards Institute, New York, 2019.

[2] S. Gagnon, E. Bilek, L. Podesto and P. Crespell, "Chapter 1: CLT Introduction to crosslaminated timber," in CLT Handboook, Pointe-Claire, FPInnovations, 2013, pp. 1-45.

[3] American Wood Council, National Design Specification (NDS) Supplement: Design Values for Wood Construction 2018 Edition, Leesburg: American Wood Council, 2018.

[4] C. Dagenais, R. H. White and K. Sumathipala, "Chapter 8: Fire performance of cross laminated timber assemblies," in CLT Handbook, Pointe-Claire, FPInnovations, 2013, pp. $1-72$.

[5] S. L. Zelinka, T. Williamson, K. Martinson and M. A. Ritter, "Research Needs Assessment for the Mass Timber Industry," in 2nd Mass Timber Research Needs Assessment, Madison, 2019.

[6] University of Arkansas, "Adohi Hall," 2020. [Online]. Available: https://wordpressua.uark.edu/southcampus/hall-facts/. [Accessed 19 June 2020].

[7] L. W. A. M. S. O. and M. M. A., Artists, Construction Drawings for Stadium Drive Residence Halls. [Art]. 2017.

[8] D. E. Breyer, K. Cobeen and Z. Martin, Design of Wood Structures ASD/LRFD, Eighth Edition, New York: McGraw Hill, 2019.

[9] American Wood Council, National Design Specification (NDS) for Wood Construction with Commentary 2018 Edition, Leesburg: American Wood Council, 2018.

[10] Binderholz, "Binderholz CLT BBS Technical Data," 2019. [Online]. Available: https://www.binderholz.com/fileadmin/user_upload/books/en/clt_bbs/6/\#zoom=z. [Accessed 17 August 2020].

[11] S. Kordziel, S. Pei, S. V. Glass, S. L. Zelinka and P. C. Tabares-Velasco, "Structure Moisture Monitoring of an 8-Story Mass Timber Building in the Pacific Northwest," Journal of Architectural Engineering, vol. 25, no. 4, 2019.

[12] E. Schmidt and M. Riggio, "Monitoring Moisture Performance of Cross-Laminated Timber Building Elements during Construction," Buildings, vol. 9, no. 144, pp. 1-23, 2019.

[13] C. Carll and A. C. Wiedenhoeft, "Moisture-Related Properties of Wood and the Effects of Moisture on Wood and Wood Products," ASTM International, West Conshohocken, 2009.

[14] WoodWorks Wood Products Council, "Building Trends: Mass Timber," March 2020. [Online]. Available: https://www.woodworks.org/publications-media/building-trendsmass-timber/. [Accessed 19 June 2020]. 
[15] M. Kottek, J. Grieser, C. Beck, B. Rudolf and F. Rubel, "World Map of the Köppen-Geiger climap classification updated," Meteorologische Zeitschrift, vol. 15, no. 3, pp. 259-263, 2006.

[16] National Oceanic \& Atmospheric Administration, "Summary of Annual Normals 19812010," 2010. [Online]. Available: https://www.ncdc.noaa.gov/cdo-web/quickdata. [Accessed 0207 2020].

[17] National Oceanic and Atmospheric Administration, "Potland (Airport) Normals (19812010), Means \& Extremes (1940-2019)," NOAA, Portland, 2020.

[18] S. V. Glass, J. Wang, S. Easley and G. Finch, "Chapter 10 Enclosure: Building enclosure design for cross-laminated timber construction," in CLT Handbook, Pointe-Claire, FPInnovations, 2018, pp. 1-36.

[19] W. L. James, "Electric moisture meters for wood," Forest Product Labratory, Madison, 1988.

[20] "ASTM Standard D4442-16, 2016, "Standard Test Methods for Direct Moisture Content Measurement of Wood and Wood-Based Materials"," ASTM International, West Conshohocken, 2016. 